\title{
Synthesis of SATE Prodrug of 6'-Fluoro-6'-methyl-5'-noradenosine Nucleoside Phosphonic Acid as a New Class of Anti-HIV Agent
}

\author{
Hua Li, Jin Cheol Yoo, Young Chan Baik, ${ }^{\dagger}$ Wonjae Lee, and Joon Hee Hong* \\ BK21-Project Team, College of Pharmacy, Chosun University, Kwangju 501-759, Korea. *E-mail: hongjh@chosun.ac.kr \\ ${ }^{\dagger}$ Hawon Pharmaceuticals Co., Pyeongtaeksi, Gyeoggido, Korea \\ Received June 23, 2010, Accepted July 15, 2010
}

\begin{abstract}
A very simple synthetic route of a novel SATE prodrug type of 6'-fluoro-6'-methyl-5'-noradeonosine carbocyclic nucleoside phosphonic acid is described. The key fluorinated alcohol intermediate 7 was prepared from the epoxide intermediate 6a via selective ring-opening of epoxide. Coupling of 7 with $N^{6}$-bis-Boc-adenine under a Mitsunobu reaction followed by phosphonation and deprotection afforded the carbocyclic phosphonic acid. The chemical stability of the bis(SATE) derivative $\mathbf{1 3}$ was measured at neutral ( $\mathrm{pH}$ 7.2) and slightly acidic (Milli-Q water, $\mathrm{pH}$ 5.5) pH. The antiviral activity test of the SATE prodrug $\mathbf{1 3}$ and its parent nucleoside phosphonic acid $\mathbf{1 1}$ were evaluated against HIV-1.
\end{abstract}

Key Words: Anti-HIV agent, SATE prodrug, Nucleoside phosphonic acid, Mitsunobu reaction

\section{Introduction}

Carbocyclic nucleosides ${ }^{1}$ are a group of compounds structurally analogous to natural and synthetic nucleosides in which the furanose oxygen has been replaced by a methylene group. This replacement changes the furanose ring into a cyclopentane. The expected similarity in bond lengths and bond angles of the tetrahydrofuran and cyclopentane rings allows these analogues to behave as substrates or inhibitors of the enzymes in living cells. Therefore, the carbocyclic nucleosides possess a wide range of biological activities such as antiviral and antitumor effects.

Although the pharmacophore of nucleoside antiviral activity is not completely defined, structurally modified 5'-nornucleoside phosphonic acids such as $\operatorname{d} 4 \mathrm{AP}\left(1, \mathrm{EC}_{50}=2.1 \mu \mathrm{M}, \mathrm{CC}_{50}=\right.$ $>100 \mu \mathrm{M})^{2}$ and $2^{\prime}-\mathrm{Fd} 4 \mathrm{AP}\left(2, \mathrm{GS}-9148, \mathrm{EC}_{50}=10.6 \mu \mathrm{M}, \mathrm{CC}_{50}=\right.$ $>100 \mu \mathrm{M})^{3}$ possess potent activity against viruses with a low level of toxicity (Figure 1). Unlike nucleoside agents, a phosphonic acid nucleoside can skip the requisite initial phosphorylation, which is the crucial step for the activation of nucleosides. ${ }^{4}$ However, poor oral bioavailability of these nucleoside analogues results from the phosphonate negative charges present in nucleoside phosphonic acid at physiological $\mathrm{pH}$. One strategy has been to temporarily mask these charges with neutral groups to form more lipophilic derivatives capable of crossing the gastrointestinal wall and reverting back to the parent nucleoside phosphonic acid. ${ }^{5}$ Because the ionic character of a phos-

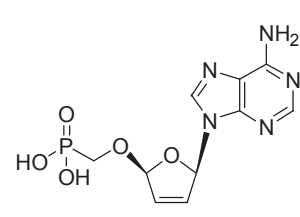

d4AP (1)

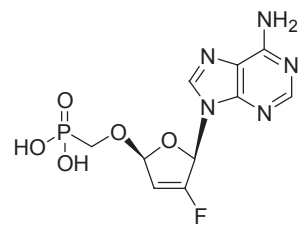

GS-9148 (2)
Figure 1. Structures of 5'-nornucleoside analogues as potent anti-HIV agents. phonic acid presents an obstacle for cellular permeability, an $S$-acyl-2-thioethyl (SATE) prodrug was prepared. Esterification of a phosphonic acid with two SATE groups is a feasible strategy to deliver a phosphate or phosphonate drug into cells. ${ }^{6}$ Usually, phosphonic acid nucleosides require an endocytosis-like process $^{7}$ or the ATP membrane receptor to cross the cell membrane. ${ }^{8}$

We therefore applied the bis(SATE) approach to a novel carbocyclic nucleoside phosphonic acid. Herein, we synthesized a novel SATE prodrug of 6'-fluoro-6'-methyl-5'-norcarbocyclic adenosine nucleoside to find new lead compounds with improved antiviral activity.

\section{Results and Discussion}

As depicted in Scheme 1, we used the cyclopentenone intermediate $\mathbf{3}$ as commercially available starting material. When $\mathbf{3}$ was subjected to Luche's reduction conditions $\left(\mathrm{NaBH}_{4} / \mathrm{CeCl}_{3}\right.$. $\left.7 \mathrm{H}_{2} \mathrm{O}\right){ }^{9}$, the allylic alcohol derivative 4 was obtained. The hydroxy functional group was protected with a benzyl group under the usual benzylation conditions $(\mathrm{BnBr}, \mathrm{NaH}, \mathrm{DMF})$ to provide an intermediate 5, which was epoxidized with $m$-chloroperoxybenzoic acid to give $\mathbf{6 a}(55 \%)$ as the major isomer compared to minor isomer $\mathbf{6 b}(22 \%)$. As shown in Figure 2, the relative stereochemistry of $\mathbf{6} \mathbf{a}$ and $\mathbf{6 b}$ were unambiguously determined on the basis of the NOE correlations. On irradiation of $\mathrm{C}_{2}-\mathrm{H}$, NOE was observed at $\mathrm{C}_{5}-\mathrm{H}(0.72 \%)$ and $\mathrm{C}_{1}-\mathrm{CH}_{3}(0.82 \%)$ of 6a, but also at $\mathrm{C}_{5}-\mathrm{H}(1.14 \%)$ and $\mathrm{C}_{1}-\mathrm{CH}_{3}(1.34 \%)$ of $\mathbf{6 b}$. This

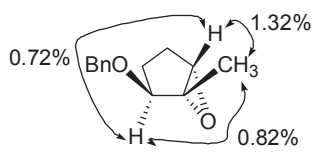

$6 a$

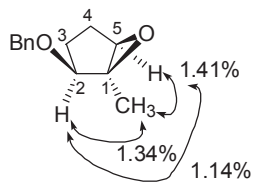

$6 b$
Figure 2. NOE percentage differences of isomers $6 \mathbf{a}$ and $\mathbf{6 b}$. 


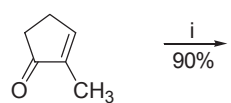

3

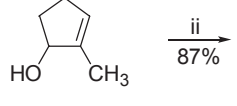

4

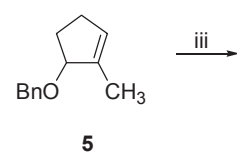

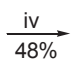

and

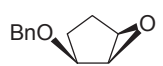

6b (22\%) $\stackrel{\mathrm{C}}{\mathrm{C}} \mathrm{H}_{3}$

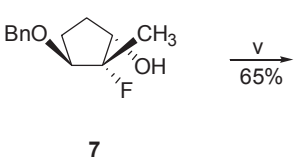

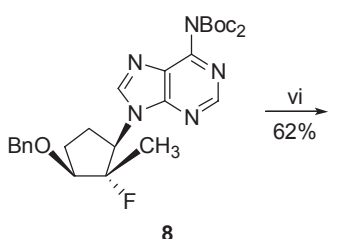
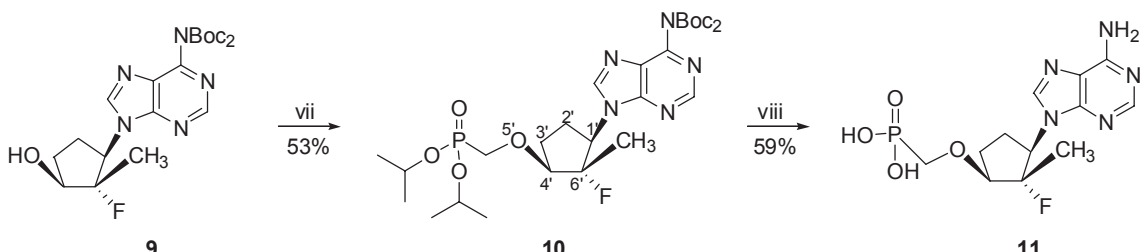

11

Reagents: i) $\mathrm{NaBH}_{4}, \mathrm{CeCl}_{3}, 7 \mathrm{H}_{2} \mathrm{O}, \mathrm{MeOH}, 0^{\circ} \mathrm{C}$; ii) $\mathrm{BnBr}, \mathrm{NaH}, \mathrm{DMF}$; iii) m-CPBA, $\mathrm{CH}_{2} \mathrm{Cl}_{2}$; iv) $47 \% \mathrm{HF}_{\text {, }}\left(\mathrm{NH}_{4}\right)_{2} \mathrm{SiF}_{6}, \mathrm{CsF}$; (v) $\mathrm{PPh}$, DIAD, $N^{6}$-bis-BOC-adenine; (vi) $\mathrm{Pa}(\mathrm{OH})_{2}$, cyclohexene, $\mathrm{MeOH}$, reflux; vii) Diisopropyl bromomethylphosphonate, LiOt${ }^{t}$-Bu, Lil, DMF, $60^{\circ} \mathrm{C}$; viii) $\mathrm{TMSBr}, \mathrm{CH}_{3} \mathrm{CN}$.

Scheme 1. Synthesis of adenine phosphonic acid nucleoside

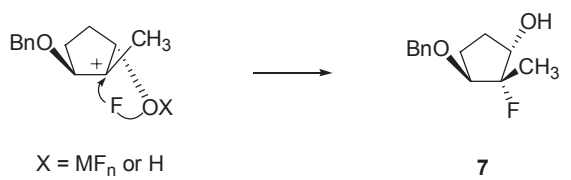

Figure 3. Possible mechanism for the formation of 7.

stereochemical outcome suggests that a non-polar group such as benzyloxy reinforces the steric hindrance to the approach of the peroxy-acid. The epoxide $\mathbf{6 a}$ was subjected to a region and stereoselective ring-opening fluorination reaction with hydrofluoric acid in the presence of silicon fluorides and additives to provide cis-fluorohydrin 7 in good yield. The formation of the cis-isomer may be due to the hydrogen bonding and/or silyl ether formation as shown in Figure 3. ${ }^{10}$

To synthesize the desired carbocyclic nucleoside analogues, the alcohol derivative 7 was subjected to a Mitsunobu coupling condition, which is the most useful and common method for the direct substitution of the hydroxyl group with an inverted configuration. ${ }^{11}$ First, $N^{6}$-bis-Boc-adenine ${ }^{12}$ was treated with the protected fluorohydrin 7 in the presence of diisopropylazodicarboxylate (DIAD) and $\mathrm{PPh}_{3}$ to give 8 in $65 \%$ yield. Hydrogenolysis of the benzyl protecting group of $\mathbf{8}$ with palladium hydroxide and cyclohexene gave the adenine derivative 9. For the synthesis of phosphonate nucleoside, the hydroxyl group of 9 was phosphonated with diisopropyl bromomethylphosphonate $^{13}$ in anhydrous DMF to give the phosphonate nucleoside intermediate 10. Both protecting groups $\left(N^{6}\right.$-bisBOC \& di-O-isopropyl) of the phosphonate nucleoside were simultaneously removed using trimethylsilylbromide ${ }^{14}$ to give nucleoside phosphonic acids $\mathbf{1 1}$. To synthesize the thioesterprotected analogues, phosphonic acid nucleoside was reacted with thioester $\mathbf{1 2}^{15}$ in the presence of 1-(2-mesitylenesulfonyl)-3-nitro- $1 H$-1,2,4-triazole (MSNT) ${ }^{16}$ to provide the final $t$-Bu-SATE prodrug 13 (Scheme 2).

The newly synthesized phosphonic nucleoside analogues 11 and its prodrug 13 were assayed in MT-4 cells for anti-HIV activity. The SATE prodrug analogue $\mathbf{1 3}$ showed enhanced cytotoxicity-dependent anti-HIV activity compared to the parent

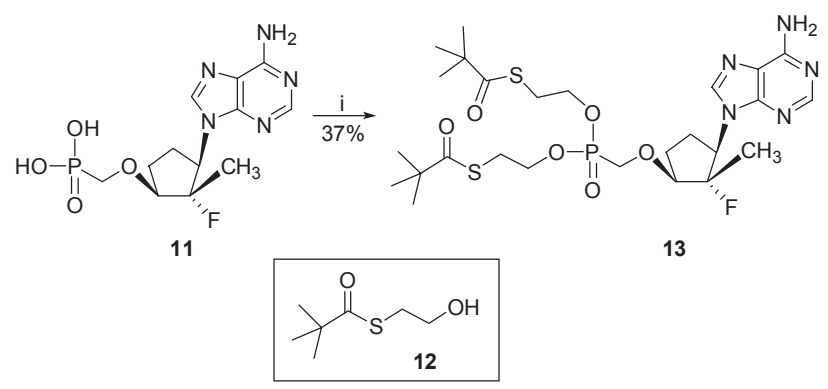

Reagents: i) 12, 1-(2-mesitylenesulfonyl)-3-nitro-1H-1,2,4-triazole, pyridine.

Scheme 2. Synthesis of target SATE prodrug 13

Table 1. Antiviral activity of the SATE derivative $\mathbf{1 3}$ and its parent nucleotide 11

\begin{tabular}{ccc}
\hline Compd & $\begin{array}{c}\text { HIV }-1 \\
\mathrm{EC}_{50}(\mu \mathrm{M})^{c}\end{array}$ & $\begin{array}{c}\text { cytotoxicity } \\
\mathrm{CC}_{50}(\mu \mathrm{M})^{d}\end{array}$ \\
\hline $\mathbf{1 1}$ & 62 & 70 \\
$\mathbf{1 3}$ & 16.7 & 31.4 \\
PMEA $_{\text {bis(SATE)PMEA }}^{a}$ & 7.8 & 12.3 \\
AZT $^{b}$ & 0.69 & 1.9 \\
\hline
\end{tabular}

bis(SATE)PMEA: bis(t-Bu-SATE)-9-[2-(phosphonomethoxy)ethyl]adenine. ${ }^{17 b}$ AZT: Azidothymidine. ${ }^{c} \mathrm{EC}_{50}(\mu \mathrm{M})$ : Concentration $(\mu \mathrm{M})$ required to inhibit the replication of HIV-1 by $50 \%$. ${ }^{d} \mathrm{CC}_{50}(\mu \mathrm{M})$ : Concentration $(\mu \mathrm{M})$ required to reduce the viability of unaffected cells by $50 \%$.

phosphonic acid 11 (Table 1).

The increased anti-HIV activity for the neutral phosphodiester derivative could result from increased cellular uptake followed by intracellular release of the parent phosphonic acid. The procedures for measuring the anti-HIV activity toward HIV-1 and cytotoxicity have been reported previously. ${ }^{18}$

To measure the relative chemical stability of the SATE prodrug using an on-line HPLC cleaning method, ${ }^{17}$ we measured the percentage of decomposition after $48 \mathrm{~h}$ for 13 at $37^{\circ} \mathrm{C}$ : (i) in Milli-Q water ( $\mathrm{pH}$ 5.5), 5.1\% decomposition was observed, and (ii) in pH 7.2 (ammonium buffer, $0.02 \mathrm{M}$ ), 5.8\% decomposition was observed. 


\section{Conclusion}

We successfully synthesized novel 6'-fluoro-6'-methyl-5'noradeonosine carbocyclic nucleoside phosphonic acid and its SATE prodrug from commercially available 2-methyl-cyclopentenone. The anti-HIV activity of the bis( $t$-Bu-SATE) prodrug 13 was higher than the parent nucleoside 11. These molecules putatively have different (potentially better) in vivo bioavailability and biodistribution than the parent nucleosides. The synthesis of other nucleoside analogues $(\mathrm{U}, \mathrm{T}, \mathrm{C})$ and enzymatic stability data will be reported elsewhere.

\section{Experimental Section}

Melting points were determined on a Mel-temp II laboratory device and are uncorrected. NMR spectra were recorded on a JEOL JNM-AL300 Fourier transform; chemical shifts are reported in parts per million $(\delta)$ and signals are reported as $\mathrm{s}$ (singlet), d (doublet), t (triplet), q (quartet), $m$ (multiplet) and dd (doublet of doublets). UV spectra were obtained on a Beckman DU-7 spectrophotometer. The elemental analyses were performed using a Perkin-Elmer 2400 analyzer. TLC was performed on Uniplates (silica gel) purchased from Analtech Co. All reactions were performed under an atmosphere of nitrogen unless specified. Dry dichloromethane, benzene, and pyridine were obtained by distillation from $\mathrm{CaH}_{2}$. Dry THF was obtained by distillation from $\mathrm{Na}$ and benzophenone immediately prior to use.

( \pm )-2-Methyl-cyclopent-2-enol (4). $\mathrm{CeCl}_{3} \cdot 7 \mathrm{H}_{2} \mathrm{O}(3.13 \mathrm{~g}$, $8.4 \mathrm{mmol}$ ) was added to a solution of $3(530 \mathrm{mg}, 5.52 \mathrm{mmol})$ in $\mathrm{MeOH}(25 \mathrm{~mL})$ at $0{ }^{\circ} \mathrm{C}$ and stirred for $30 \mathrm{~min}$. Then, $\mathrm{NaBH}_{4}$ $(416 \mathrm{mg}, 11.0 \mathrm{mmol})$ was carefully added to the mixture and stirred for $3 \mathrm{~h}$ at $\mathrm{rt}$. The reaction mixture was quenched by addition of acetic acid $(1.0 \mathrm{~mL})$ and concentrated under reduced pressure. The resulting residue was diluted with $\mathrm{H}_{2} \mathrm{O}$ $(100 \mathrm{~mL})$ and extracted with EtOAc $(2 \times 100 \mathrm{~mL})$. The organic layer was sequentially washed with sat. $\mathrm{NaHCO}_{3}(100 \mathrm{~mL})$ and brine $(100 \mathrm{~mL})$. The organic phase was dried over anhydrous magnesium sulfate, filtered, concentrated in vacuo, and purified by column chromatography (EtOAc/hexane, 1:5) to give compound 4 (487 mg, 90\%) as a colorless oil: ${ }^{1} \mathrm{H} \mathrm{NMR}\left(\mathrm{CDCl}_{3}\right.$, $300 \mathrm{MHz}) \delta 5.39(\mathrm{dd}, J=5.8,2.6 \mathrm{~Hz}, 1 \mathrm{H}), 4.07(\mathrm{dd}, J=6.0$, $2.8 \mathrm{~Hz}, 1 \mathrm{H}), 2.34-2.22(\mathrm{~m}, 2 \mathrm{H}), 1.94(\mathrm{~m}, 2 \mathrm{H}), 1.80(\mathrm{~s}, 3 \mathrm{H}) ;{ }^{13} \mathrm{C}$ NMR $\left(\mathrm{CDCl}_{3}\right) \delta 138.6,123.2,83.9,29.6,26.2,16.9$.

( \pm )-(2-Methyl-cyclopent-2-enyloxymethyl) benzene (5). To a solution of enol derivative 4 (439 $\mathrm{mg}, 4.48 \mathrm{mmol}$ ) in dry DMF $(10 \mathrm{~mL})$ was slowly added $\mathrm{NaH}(129 \mathrm{mg}, 5.37 \mathrm{mmol})$ at $0{ }^{\circ} \mathrm{C}$. After $30 \mathrm{~min}$, benzyl bromide ( $840 \mathrm{mg}, 4.92 \mathrm{mmol}$ ) was added, and the reaction mixture was stirred for $5 \mathrm{~h}$ at $\mathrm{rt}$. The mixture was quenched by adding of saturated ammonium chloride $(2 \mathrm{~mL})$ and concentrated in a high vacuum. The residue was diluted with water $(50 \mathrm{~mL})$ and with EtOAc $(2 \times 30 \mathrm{~mL})$. The combined organic layer was washed with brine and dried over anhydrous $\mathrm{MgSO}_{4}$, filtered, and evaporated. The filtrate was concentrated under reduced pressure and the residue was purified by silica gel column chromatography (EtOAc/hexane, 1:25) to give $\mathbf{5}$ (733 mg, 87\%) as a colorless oil. ${ }^{1} \mathrm{H} \mathrm{NMR}\left(\mathrm{CDCl}_{3}, 300 \mathrm{MHz}\right)$ $\delta 7.33-7.25(\mathrm{~m}, 5 \mathrm{H}), 5.21(\mathrm{~m}, 1 \mathrm{H}), 4.59(\mathrm{~s}, 2 \mathrm{H}), 3.52$ (dd, $J=8.4$,
$5.2 \mathrm{~Hz}, 1 \mathrm{H}), 2.35(\mathrm{~m}, 2 \mathrm{H}), 2.05(\mathrm{~m}, 2 \mathrm{H}), 1.66(\mathrm{~s}, 3 \mathrm{H}) ;{ }^{13} \mathrm{C} \mathrm{NMR}$ $\left(\mathrm{CDCl}_{3}\right) \delta 138.3,128.7,127.5,127.0,126.3,123.4,84.2,74.1$, 27.8, 25.6, 15.9.

(rel)-(1R,2S,5S)-2-Benzyloxy-1-methyl-6-oxa-bicyclo [3.1.0] hexane (6a) and (rel)-(1S,2S,5R)-2-benzyloxy-1-methyl-6-oxa-bicyclo[3.1.0] hexane (6b). $m$-Chloroperbenzoic acid (1.82 g, $7.8 \mathrm{mmol}, 77 \%$ purity) was added to a solution of $\mathbf{5}$ $(1.12 \mathrm{~g}, 5.98 \mathrm{mmol})$ in anhydrous $\mathrm{CH}_{2} \mathrm{Cl}_{2}(40 \mathrm{~mL})$ at $0{ }^{\circ} \mathrm{C}$. The solution was stirred at $0{ }^{\circ} \mathrm{C}$ for $2 \mathrm{~h}$ and stirred for an additional $2 \mathrm{~h}$ at rt. A saturated $\mathrm{NaHCO}_{3}$ solution $(80 \mathrm{~mL})$ was added to the reaction mixture and extracted with EtOAc $(2 \times 80 \mathrm{~mL})$. The combined organic layer was washed with brine, dried over anhydrous magnesium sulfate, filtered, concentrated in vacuo, and purified by column chromatography (EtOAc/hexane, 1:8) to give compound $\mathbf{6 a}(672 \mathrm{mg}, 55 \%)$ and $\mathbf{6 b}(269 \mathrm{mg}, 22 \%)$ as syrup, respectively: Compound 6a: ${ }^{1} \mathrm{H} \mathrm{NMR}\left(\mathrm{CDCl}_{3}, 300 \mathrm{MHz}\right)$ $\delta 7.31-7.25(\mathrm{~m}, 5 \mathrm{H}), 4.58(\mathrm{~s}, 2 \mathrm{H}), 3.21(\mathrm{dd}, J=6.2,4.8 \mathrm{~Hz}, 1 \mathrm{H})$, $2.58(\mathrm{~m}, 1 \mathrm{H}), 1.71-1.62(\mathrm{~m}, 4 \mathrm{H}), 1.35(\mathrm{~s}, 3 \mathrm{H}) ;{ }^{13} \mathrm{C} \mathrm{NMR}\left(\mathrm{CDCl}_{3}\right)$ $\delta 137.9,128.4,127.6,126.2,82.9,75.6,70.4,64.4,21.1,16.5$, 14.3; Anal. Calcd. for $\mathrm{C}_{13} \mathrm{H}_{16} \mathrm{O}_{2}$ : C, 76.44; H, 7.90. Found: $\mathrm{C}$, 76.41; H, 7.89; Compound 6b: ${ }^{1} \mathrm{H} \mathrm{NMR}\left(\mathrm{CDCl}_{3}, 300 \mathrm{MHz}\right) \delta$ $7.35-7.29$ (m, 5H), 4.60 (s, 2H), 3.27 (dd, $J=6.4,4.8 \mathrm{~Hz}, 1 \mathrm{H})$, $2.62(\mathrm{dd}, J=6.8,5.2 \mathrm{~Hz}, 1 \mathrm{H}), 1.69-1.58(\mathrm{~m}, 4 \mathrm{H}), 1.41(\mathrm{~s}, 3 \mathrm{H})$; ${ }^{13} \mathrm{C} \mathrm{NMR}\left(\mathrm{CDCl}_{3}\right) \delta 137.4,128.1,127.7,126.4,83.5,76.3$, 71.7, 65.7, 23.5, 17.7, 14.9; Anal. Calcd. for $\mathrm{C}_{13} \mathrm{H}_{16} \mathrm{O}_{2}$ : C, 76.44; H, 7.90. Found: C, 76.48; H, 7.93.

(rel)-(1S,2S,3S)-3-Benzyloxy-2-fluoro-2-methyl-cyclopentanol (7). To a mixture of $\left(\mathrm{NH}_{4}\right)_{2} \mathrm{SiF}_{6}(1.068 \mathrm{~g}, 6.0 \mathrm{mmol})$, CsF (182.3 mg, $1.2 \mathrm{mmol})$ and epoxide 6a(245 mg, $1.2 \mathrm{mmol})$ in 1,2-dichloroethane $(15 \mathrm{~mL})$ was added $47 \%$ hydrofluoric acid $(0.152 \mathrm{~mL}, 3.6 \mathrm{mmol})$ and $i \operatorname{Pr}_{2} \mathrm{NEt}(0.21 \mathrm{~mL}, 1.2 \mathrm{mmol})$ at $0{ }^{\circ} \mathrm{C}$, and the mixture was stirred for $5 \mathrm{~h}$ at $0{ }^{\circ} \mathrm{C}$. A saturated $\mathrm{NaHCO}_{3}$ solution $(15 \mathrm{~mL})$ was slowly added and the mixture was extracted with diethyl ether $(2 \times 80 \mathrm{~mL})$. The combined organic layer was washed with brine and dried over anhydrous $\mathrm{MgSO}_{4}$, filtered, and evaporated. The filtrate was concentrated under vacuum and the residue was purified by silica gel column chromatography (EtOAc/hexane, 1:12) to give alcohol 7 (129 $\mathrm{mg}, 48 \%)$ as a colorless oil: ${ }^{1} \mathrm{H}$ NMR $\left(\mathrm{CDCl}_{3}, 300 \mathrm{MHz}\right) \delta$ 7.33-7.25 (m, 5H), 4.60 (s, 2H), 3.73 (ddd, $J=2.8,6.4,19.8$ $\mathrm{Hz}, 1 \mathrm{H}), 3.21(\mathrm{dd}, J=5.4,14.2 \mathrm{~Hz}, 1 \mathrm{H}), 1.70(\mathrm{~m}, 2 \mathrm{H}), 1.62$ $(\mathrm{m}, 2 \mathrm{H}), 1.30(\mathrm{~d}, J=21.2 \mathrm{~Hz}, 3 \mathrm{H}) ;{ }^{13} \mathrm{C} \mathrm{NMR}\left(\mathrm{CDCl}_{3}\right) \delta 137.8$, $128.3,127.8,126.7,104.2$ (d, $J=180.8 \mathrm{~Hz}), 81.3$ (d, $J=44.0$ $\mathrm{Hz}), 76.4(\mathrm{~d}, J=19.2 \mathrm{~Hz}), 73.8,20.3,17.4,13.4$ (d, $J=22.2 \mathrm{~Hz})$; Anal. Calcd. for $\mathrm{C}_{13} \mathrm{H}_{17} \mathrm{FO}_{2}$ : C, 69.62; H, 7.64. Found: C, 69.59; H, 7.61 .

(rel)-(1R,2S,3S)-9-(3-Benzyloxy-2-fluoro-2-methyl-cyclopentan-1-yl) $\boldsymbol{N}^{6}$-bis-Boc-adenine (8). To a stirred solution of triphenylphosphine $(673 \mathrm{mg}, 2.57 \mathrm{mmol})$ in dry THF $(15 \mathrm{~mL})$ at $0{ }^{\circ} \mathrm{C}$ was added dropwise the diisopropyl azodicarboxylate (DIAD) (518 mg, $2.57 \mathrm{mmol}$ ), and the reaction mixture was stirred at this temperature for $30 \mathrm{~min}$. After that, a solution of the fluorinated alcohol 7 (287 mg, $1.28 \mathrm{mmol})$ in THF $(15 \mathrm{~mL})$ was added and the reaction mixture was stirred at $0{ }^{\circ} \mathrm{C}$ for 30 $\min$. Then the cold bath was removed and the yellow solution was stirred for $30 \mathrm{~min}$ at room temperature. $N^{6}$-bis-Boc adenine (861 mg, $2.57 \mathrm{mmol}$ ) was then added and the reaction mixture was stirred overnight at room temperature. The reaction mix- 
ture was concentrated under reduced pressure and the residue was purified by silica gel column chromatography (EtOAc/ hexane, 2:1) to give compound $8(450 \mathrm{mg}, 65 \%)$ as a white solid; mp 167 - $169{ }^{\circ} \mathrm{C} ;{ }^{1} \mathrm{H} \mathrm{NMR}\left(\mathrm{CDCl}_{3}, 300 \mathrm{MHz}\right) \delta 8.86$ (s, $1 \mathrm{H}), 7.85(\mathrm{~s}, 1 \mathrm{H}), 7.31-7.24(\mathrm{~m}, 5 \mathrm{H}), 4.69(\mathrm{~s}, 2 \mathrm{H}), 4.01(\mathrm{dd}, J=$ $5.6,17.6 \mathrm{~Hz}, 1 \mathrm{H}), 3.18$ (ddd, $J=2.2,6.0,15.4 \mathrm{~Hz}, 1 \mathrm{H}), 2.01$ $(\mathrm{m}, 2 \mathrm{H}), 1.75(\mathrm{~m}, 2 \mathrm{H}), 1.41(\mathrm{~d}, J=21.8 \mathrm{~Hz}, 3 \mathrm{H}), 1.35(\mathrm{~s}, 18 \mathrm{H})$; ${ }^{13} \mathrm{C} \mathrm{NMR}\left(\mathrm{CDCl}_{3}\right) \delta 155.0,152.3,150.5,147.7,143.5,138.3$, $128.7,128.0,127.3,101.3(\mathrm{~d}, J=179.8 \mathrm{~Hz}), 82.9,80.2(\mathrm{~d}, J=$ $40.8 \mathrm{~Hz}), 74.0,58.6$ (d, $J=18.2 \mathrm{~Hz}), 27.7,17.2,15.5,14.2(\mathrm{~d}$, $J=24.4 \mathrm{~Hz}$ ); Anal. Calcd. for $\mathrm{C}_{28} \mathrm{H}_{36} \mathrm{FN}_{5} \mathrm{O}_{5}$ : C, 62.09; $\mathrm{H}, 6.70$; N, 12.93. Found: C, 62.12; H, 6.68; N, 12.89.

(rel)-(1R,2S,3S)-9-(3-Hydroxy-2-fluoro-2-methyl-cyclopentan-1-yl) $\boldsymbol{N}^{6}$-bis-Boc-adenine (9). A solution of 8 (230 mg, $0.425 \mathrm{mmol})$ in $\mathrm{MeOH}(10 \mathrm{~mL})$ was treated with palladium hydroxide $\left(80 \mathrm{mg}, 20 \%\right.$ in activated charcoal) at $0{ }^{\circ} \mathrm{C}$. Cyclohexene $(5 \mathrm{~mL})$ was added and the reaction mixture was refluxed overnight. The suspension was cooled to room temperature, filtered over Celite, and the filtrates were concentrated. The residue was purified by silica gel column chromatography (EtOAc/hexane/MeOH, 4:1:0.05) to give compound 9 (119 mg, 62\%) as a white solid: $\mathrm{mp} 175-177{ }^{\circ} \mathrm{C} ;{ }^{1} \mathrm{H} \mathrm{NMR}\left(\mathrm{CDCl}_{3}\right.$, $300 \mathrm{MHz}) \delta 8.81(\mathrm{~s}, 1 \mathrm{H}), 7.83(\mathrm{~s}, 1 \mathrm{H}), 4.70(\mathrm{~s}, 2 \mathrm{H}), 4.00(\mathrm{dd}$, $J=5.7,18.0 \mathrm{~Hz}, 1 \mathrm{H}), 3.18(\mathrm{ddd}, J=2.2,6.0,15.4 \mathrm{~Hz}, 1 \mathrm{H})$, $2.04(\mathrm{~m}, 2 \mathrm{H}), 1.77(\mathrm{~m}, 2 \mathrm{H}), 1.39$ (d, $J=21.8 \mathrm{~Hz}, 3 \mathrm{H}), 1.34$ (s, $18 \mathrm{H}) ;{ }^{13} \mathrm{C} \mathrm{NMR}\left(\mathrm{CDCl}_{3}\right) \delta 153.7,152.6,150.6,147.3,142.4$, $127.5,102.6(\mathrm{~d}, J=176.6 \mathrm{~Hz}), 82.4,79.9$ (d, $J=42.4 \mathrm{~Hz}), 73.6$, $57.8(\mathrm{~d}, J=17.8 \mathrm{~Hz}), 28.0,17.7,15.6,14.1$ (d, $J=22.0 \mathrm{~Hz})$; Anal. Calcd. for $\mathrm{C}_{21} \mathrm{H}_{30} \mathrm{FN}_{5} \mathrm{O}_{5}$ : C, 55.86; H, 6.70; N, 15.51 . Found: C, 55.83; H, 6.72; N, 15.49 .

(rel)-(1R,2S,3S)-[3-( $N^{6}$-Bis-Boc-adenine-9-yl)-2-fluoro-2methyl-cyclopentyloxymethyl]-phosphonic acid diisopropyl ester (10). To a solution of the cyclopentenol 9 (1.92 g, 4.25 $\mathrm{mmol}$ ) in $15 \mathrm{~mL}$ of DMF was added LiI (42.68 mg, $0.32 \mathrm{mmol})$ at rt. Both LiO- $t \mathrm{Bu}(6.8 \mathrm{~mL}$ of $1.0 \mathrm{M}$ solution in THF, 6.8 $\mathrm{mmol}$ ) and a solution of diisopropyl bromomethylphosphonate $(1.38 \mathrm{~mL}, 5.76 \mathrm{mmol})$ in $10 \mathrm{~mL}$ of DMF were slowly added to the reaction mixture and stirred for $3 \mathrm{~h}$ at $60^{\circ} \mathrm{C}$ under anhydrous conditions. The mixture was quenched by adding water $(10 \mathrm{~mL})$ and the organic solvents were removed in vacuo. The residue was diluted with water $(80 \mathrm{~mL})$ and was extracted with EtOAc $(3 \times 80 \mathrm{~mL})$. The combined extracts were washed with brine, dried over $\mathrm{MgSO}_{4}$, and concentrated in vacuo. The residue was purified by silica gel column chromatography $\left(\mathrm{CH}_{2} \mathrm{Cl}_{2} / \mathrm{MeOH}\right.$, $10: 1)$ to give $10(1.42 \mathrm{~g}, 53 \%)$ as a solid: $\mathrm{mp} 162-164{ }^{\circ} \mathrm{C} ;{ }^{1} \mathrm{H}$ $\mathrm{NMR}\left(\mathrm{CDCl}_{3}, 300 \mathrm{MHz}\right) \delta 8.87(\mathrm{~s}, 1 \mathrm{H}), 7.86(\mathrm{~s}, 1 \mathrm{H}), 4.71(\mathrm{~m}$, $2 \mathrm{H}), 4.03(\mathrm{ddd}, J=1.8,6.0,18.8 \mathrm{~Hz}, 1 \mathrm{H}), 3.62(\mathrm{~d}, J=8.8 \mathrm{~Hz}$, $2 \mathrm{H}), 3.18$ (ddd, $J=1.8,6.2,14.6 \mathrm{~Hz}, 1 \mathrm{H}), 2.01(\mathrm{~m}, 2 \mathrm{H}), 1.69$ (m, $2 \mathrm{H}), 1.38(\mathrm{~d}, J=20.6 \mathrm{~Hz}, 3 \mathrm{H}), 1.36(\mathrm{~s}, 12 \mathrm{H}), 1.34(\mathrm{~s}, 18 \mathrm{H})$; ${ }^{13} \mathrm{C} \mathrm{NMR}\left(\mathrm{CDCl}_{3}\right) \delta 153.8,152.3,150.9,150.3,142.7,130.4$, $101.4(\mathrm{~d}, J=173.2 \mathrm{~Hz}), 83.6,82.0(\mathrm{~d}, J=43.4 \mathrm{~Hz}), 70.4,65.4$, $59.5(\mathrm{~d}, J=16.8 \mathrm{~Hz}), 28.1,23.6,17.2,15.1,14.2$ (d, $J=20.8 \mathrm{~Hz})$; Anal. Calcd. for $\mathrm{C}_{28} \mathrm{H}_{45} \mathrm{FN}_{5} \mathrm{O}_{8} \mathrm{P} \cdot 0.5 \mathrm{MeOH}$ : C, 53.01; H, 7.33; N, 10.85. Found: C, 52.97; H, 7.35; N, 10.81 .

(rel)-(1R,2S,3S)-[3-(6-Amino-purin-9-yl)-2-fluoro-2-methyl-cyclopentyloxymethyl]-phosphonic acid (11). To a solution of the phosphonate $\mathbf{1 0}$ (104 mg, $0.165 \mathrm{mmol}$ ) in $\mathrm{CH}_{3} \mathrm{CN}$ $(11 \mathrm{~mL})$ was added trimethylsilyl bromide $(252 \mathrm{mg}, 1.665$ mmol). The mixture was heated overnight at $60{ }^{\circ} \mathrm{C}$ and concentrated under reduced pressure. The residue was partitioned between pure $\mathrm{CH}_{2} \mathrm{Cl}_{2}(16 \mathrm{~mL})$ and distilled $\mathrm{H}_{2} \mathrm{O}(16 \mathrm{~mL})$. The aqueous layer was washed out with $\mathrm{CH}_{2} \mathrm{Cl}_{2}$ and then freezedried to give target compound $\mathbf{1 1}(33.6 \mathrm{mg}, 59 \%)$ as a yellowish foamy solid. UV $\left(\mathrm{H}_{2} \mathrm{O}\right) \lambda_{\max } 262.5 \mathrm{~nm} ;{ }^{1} \mathrm{H}$ NMR (DMSO- $d_{6}$, $300 \mathrm{MHz}) \delta 8.86(\mathrm{~s}, 1 \mathrm{H}), 7.85(\mathrm{~s}, 1 \mathrm{H}), 4.01(\mathrm{dd}, J=6.2,20.4$ $\mathrm{Hz}, 1 \mathrm{H}), 3.60(\mathrm{~d}, J=8.6 \mathrm{~Hz}, 2 \mathrm{H}), 3.17(\mathrm{dd}, J=6.1,16.2 \mathrm{~Hz}, 1 \mathrm{H})$, $2.08(\mathrm{~m}, 2 \mathrm{H}), 1.71(\mathrm{~m}, 2 \mathrm{H}), 1.37(\mathrm{~d}, J=20.2 \mathrm{~Hz}, 3 \mathrm{H}) ;{ }^{13} \mathrm{CNMR}$ $\left(\mathrm{DMSO}-d_{6}\right) \delta 155.4,152.7,150.5,142.3,120.4,101.1(\mathrm{~d}, J=$ $172.4 \mathrm{~Hz}), 82.6(\mathrm{~d}, J=40.8 \mathrm{~Hz}), 64.6,58.9(\mathrm{~d}, J=18.3 \mathrm{~Hz}), 17.3$, 15.1, 14.2 (d, $J=22.8 \mathrm{~Hz}$ ); Anal. Calcd. for $\mathrm{C}_{12} \mathrm{H}_{17} \mathrm{FN}_{5} \mathrm{O}_{4} \mathrm{P}$. $2.0 \mathrm{H}_{2} \mathrm{O}: \mathrm{C}, 37.80 ; \mathrm{H}, 5.55 ; \mathrm{N}, 18.37$. Found: $\mathrm{C}, 37.83 ; \mathrm{H}, 5.52$; $\mathrm{N}, 18.35$.

(rel)-(1R,2S,3S)-t-Butyl SATE phosphoester of 9-(2-fluoro2-methyl-cyclopentyloxymethan-1-yl) adenine (13). A solution of adenine phosphonic acid derivative 11 (81.6 mg, 0.254 mmol) and tributylamine $(432 \mu \mathrm{L}, 1.728 \mathrm{mmol})$ in methanol $(8.6 \mathrm{~mL})$ was mixed for $30 \mathrm{~min}$ and concentrated under reduced pressure. The residue was thoroughly dried with anhydrous ethanol and toluene. The resulting foamy solid was dissolved in anhydrous pyridine $(16 \mathrm{~mL})$ to which thioester $12(389 \mathrm{mg}$, $2.37 \mathrm{mmol})$ and 1-(2-mesitylenesulfonyl)-3-nitro- $1 H-1,2,4-$ triazole $(319 \mathrm{mg}, 1.08 \mathrm{mmol})$ were added. The mixture was stirred for $16 \mathrm{~h}$ at room temperature and quenched with tetrabutylammonium bicarbonate buffer $(12 \mathrm{~mL}, 1 \mathrm{M}$ solution, $\mathrm{pH}$ 8.0). The mixture was concentrated under reduced pressure and the residue was diluted with water $(100 \mathrm{~mL})$ and extracted twice with $\mathrm{CH}_{2} \mathrm{Cl}_{2}(100 \mathrm{~mL})$. The combined organic layer was washed with brine, dried over $\mathrm{MgSO}_{4}$, filtered, and evaporated. The residue was purified by silica gel column chromatography (Hexane/EtOAc/MeOH, 4:1:0.01) to give 13 (59 mg, 37\%) as a solid: mp $125-127{ }^{\circ} \mathrm{C}$; UV (MeOH) $\lambda_{\max } 261.5 \mathrm{~nm} ;{ }^{1} \mathrm{H}$ NMR $\left(\mathrm{CDCl}_{3}, 300 \mathrm{MHz}\right) \delta 8.79(\mathrm{~s}, 1 \mathrm{H}), 7.80(\mathrm{~s}, 1 \mathrm{H}), 4.05-4.00(\mathrm{~m}$, $5 \mathrm{H}), 3.61(\mathrm{~d}, J=8.8 \mathrm{~Hz}, 2 \mathrm{H}), 3.17-3.14(\mathrm{~m}, 5 \mathrm{H}), 2.05(\mathrm{~m}, 2 \mathrm{H})$, $1.75(\mathrm{~m}, 2 \mathrm{H}), 1.38(\mathrm{~d}, J=21.2 \mathrm{~Hz}, 3 \mathrm{H}), 1.20(\mathrm{~s}, 18 \mathrm{H}) ;{ }^{13} \mathrm{C} \mathrm{NMR}$ $\left(\mathrm{CDCl}_{3}\right) \delta 205.1,154.7,151.9,149.4,143.6,119.6,103.2(\mathrm{~d}$, $J=170.8 \mathrm{~Hz}), 81.7(\mathrm{~d}, J=38.2 \mathrm{~Hz}), 64.4,62.2,57.8(\mathrm{~d}, J=$ $20.4 \mathrm{~Hz}$ ), 46.2, 30.5, 26.2, 18.1, 16.0, 14.5 (d, $J=20.2 \mathrm{~Hz}$ ); Anal. Calcd. for $\mathrm{C}_{26} \mathrm{H}_{41} \mathrm{FN}_{5} \mathrm{O}_{6} \mathrm{PS}_{2} \cdot 1.0 \mathrm{MeOH}$ : C, 48.71; H, 6.81 ; N, 10.52. Found: C, 48.68; H, 6.83; N, 10.49.

\section{References}

1. (a) Borthwick, A. D.; Biggadike, K. Tetrahedron 1992, 48, 571. (b) Huryn, D. M.; Okabe, M. Chem. Rev. 1992, 92, 1745. (c) Agrofoglio, L.; Suhas, E.; Farese, A.; Condom, R.; Challand, S.; Earl, R. A.; Guedj, R. Tetrahedron 1994, 50, 10611. (d) Crimmins, M. T. Tetrahedron 1998, 54, 9229. (e) Ariona, O.; Gómez, A. M.; López, J. C.; Plumet, J. Chem. Rev. 2007, 107, 1919.

2. (a) Zemlicka, J.; Gasser, R.; Freisler, J. V.; Horwitz, J. P. J. Am. Chem. Soc. 1972, 94, 3213. (b) Mackman, R. L.; Boojamra, C. G.; Prasad, V.; Zhang, L.; Lin, K. Y.; Petrakovsky, O.; Babusis, D.; Chen, J.; Douglas, J.; Grant, D.; Hui, H. C.; Kim, C. U.; Markevitch, D. Y.; Vela, J.; Ray, A.; Cihlar, T. Bioorg. Med. Chem. Lett. 2007, 17, 6785 .

3. (a) Boojamra, C. G.; Mackman, R. L.; Markevitch, D. Y.; Prasad, V.; Ray, A. S.; Douglas, J.; Grant, D.; Kim, C. U.; Cihlar, T. Bioorg. Med. Chem. Lett. 2008, 18, 1120. (b) Mackman, R. L.; Lin, K. Y.; Boojamra, C. G.; Hui, H.; Douglas, J.; Grant, D.; Petrakovsky, O.; Prasad, V.; Ray, A. S.; Cihlar, T. Bioorg. Med. Chem. Lett. 2008, 
$18,1116$.

4. Jones, R. J.; Bischofberger, N. Antiviral Res. 1995, 27, 1.

5. Srinivas, R. V.; Robbins, B. L.; Connelly, M. C.; Gong, Y. F.; Bischofberger, N.; Fridland, A. Antimicrob. Agents Chemother. 1993, 37, 2247.

6. (a) Perigaud, C.; Aubertin, A. M.; Benzaria, S.; Pelicano, H.; Girardet, J. L.; Maury, G.; Gosselin, G.; Kirn, A.; Imbach, J. L. Biochem. Pharmacol. 1994, 48, 11. (b) Girardet, J. L.; Perigaud, C.; Aubertin, A. M.; Gosselin, G.; Kirn, A.; Imbach, J. L. Bioorg. Med. Chem. Lett. 1995, 5, 2981.

7. Palú, G.; Stefanelli, S.; Rassu, M.; Parolin, C.; Balzarini, J.; De Clercq, E. Antiviral Res. 1991, 16, 115.

8. Naesens, L.; Balzarini, J.; De Clercq, E. Rev. Med. Virol. 1994, 4, 147.

9. Sirbu, D.; Falck-Pedersen, M. L.; Romming, C.; Undheim, K. Tetrahedron 1999, 55, 6703.

10. Shimizu, M.; Nakahara, Y. J. Fluorine Chem. 1999, 99, 95.

11. Kitade, Y.; Ando, T.; Yamaguchi, T.; Hori, A.; Nakanishi, M.; Ueno,
Y. Bioorg. Med. Chem. 2006, 14, 5578.

12. Michel, B. Y.; Peter, S. Tetrahedron 2007, 63, 9836.

13. (a) Kim, A.; Oh, C. H.; Hong, J. H. Nucleosides Nucleotides Nucleic Acids 2006, 25, 1399. (b) Kim, A.; Hong. J. H. Nucleosides Nucleotides Nucleic Acids 2006, 25, 1.

14. Liu, L. J.; Seo, R. S.; Yoo, S. W.; Choi, J.; Hong, J. H. Bull. Korean Chem. Soc. 2010, 31, 915.

15. Lefebvre, I.; Périgaud, C.; Pompon, A.; Aubertin, A. M.; Girardet, J. L.; Kirn, A.; Gosselin, G.; Imbach, J. L. J. Med. Chem. 1995, 38,3941

16. Périgaud, C.; Gosselin, G.; Lefebvre, I.; Girardet, J. L.; Benzaria, S.; Barber, I.; Imbach, J. L. Bioorg. Med. Chem. Lett. 1993, 3, 2521.

17. (a) Benzaria, S.; Pélicano, H.; Johnson, R.; Maury, G.; Imbach, J. L.; Aubertin, A. M.; Obert, G.; Gosselin, G. J. Med. Chem. 1996, 39, 4958. (b) Pompon, A.; Lefebvre, I.; Imbach, J. L.; Kahn, S.; Farquhar, D. Antiviral Chem. Chemother. 1994, 5, 91.

18. Lian, L. J.; Yoo, J. C.; Hong, J. H. Nucleosides Nucleotides Nucleic Acids 2009, 28, 150. 